\title{
Nevada Test Site
}

\section{Environmental Report Summary 2007}

September 2008

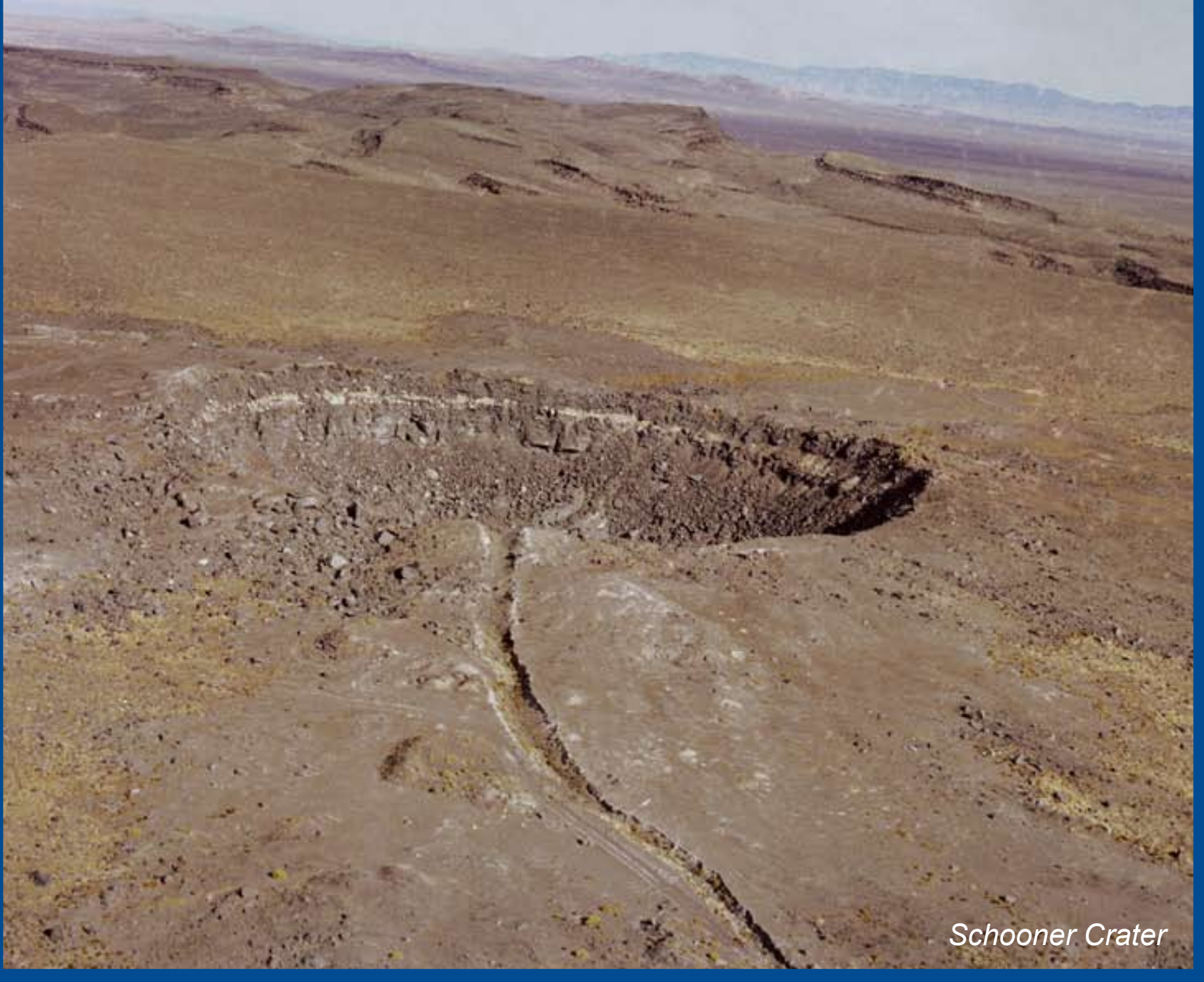




\title{
Disclaimer
}

Reference herein to any specific commercial product, process, or service by trade name, trademark, manufacturer, or otherwise, does not necessarily constitute or imply its endorsement, recommendation, or favoring by the United States Government or any agency thereof.

\section{Availability}

Available for sale to the public from:

U.S. Department of Commerce

National Technical Information Service

5285 Port Royal Road

Springfield, VA 22161-0002

Telephone: (800) 553-6847

Fax: (703) 605-6900

E-mail: orders@ntis.gov

Online ordering: http://www.ntis.gov/ordering.htm

Available electronically at http://www.osti.gov/bridge

Available for a processing fee to the U.S. Department of Energy and its contractors, in paper, from:

\author{
U.S. Department of Energy \\ Office of Scientific and Technical Information \\ P.O. Box 62 \\ Oak Ridge, TN 37831-0062 \\ Telephone: (865) 576-8401 \\ Fax: (865) 576-5728 \\ E-mail: reports@adonis.osti.gov
}

The information presented in this document is explained in greater detail in the Nevada Test Site Environmental Report 2007 (DOE/NV/25946--543). A compact disc of this document is included on the back inside cover. This document can also be downloaded from the National Nuclear Security Administration Nevada Site Office at http://www.nv.doe.gov/library/publications/environmental.aspx.

For more information about the Nevada Test Site's Environmental Report, contact Bruce Hurley at (702) 295-1284 or hurley@nv.doe.gov.

\author{
This report was prepared for: \\ U.S. Department of Energy \\ National Nuclear Security Administration \\ Nevada Site Office \\ under Contract DE-AC52-06NA25946 \\ by: \\ National Security Technologies, LLC \\ Post Office Box 98521 \\ Las Vegas, NV 89193-8521
}




\section{Nevada Test Site}

\section{Environmental Report Summary 2007}

The U.S. Department of Energy, National Nuclear Security Administration Nevada Site Office (NNSA/NSO) directs the management and operation of the Nevada Test Site (NTS). The NTS is the nation's historical testing site for nuclear weapons from 1951 through 1992 and is currently the nation's unique site for ongoing national-securityrelated missions and high-risk operations. NNSA/NSO strives to provide to the public an understanding of the current activities on the NTS, including environmental monitoring and compliance activities aimed at protecting the public and the environment from radiation hazards and from nonradiological impacts. This document is a summary of the Nevada Test Site Environmental Report (NTSER) for calendar year 2007 (see attached compact disc on inside back cover). The NTSER is a comprehensive report of environmental activities performed at the NTS and offsite facilities over the previous calendar year. It is prepared annually to meet the requirements and guidelines of the U.S. Department of Energy (DOE) and the information needs of NNSA/NSO stakeholders. To provide an abbreviated and more readable version of the NTSER, this summary report is produced. This summary does not include detailed data tables, monitoring methods or design, a description of the NTS environment, or a discussion of all environmental program activities performed throughout the year. The reader may obtain a hard copy of the full NTSER as directed on the inside front cover of this summary report.

The NTS is located about 65 miles northwest of Las Vegas. The approximately 1,375-square mile site is one of the largest restricted access areas in the United States. It is surrounded by federal installations with strictly controlled access as well as by lands that are open to public entry.

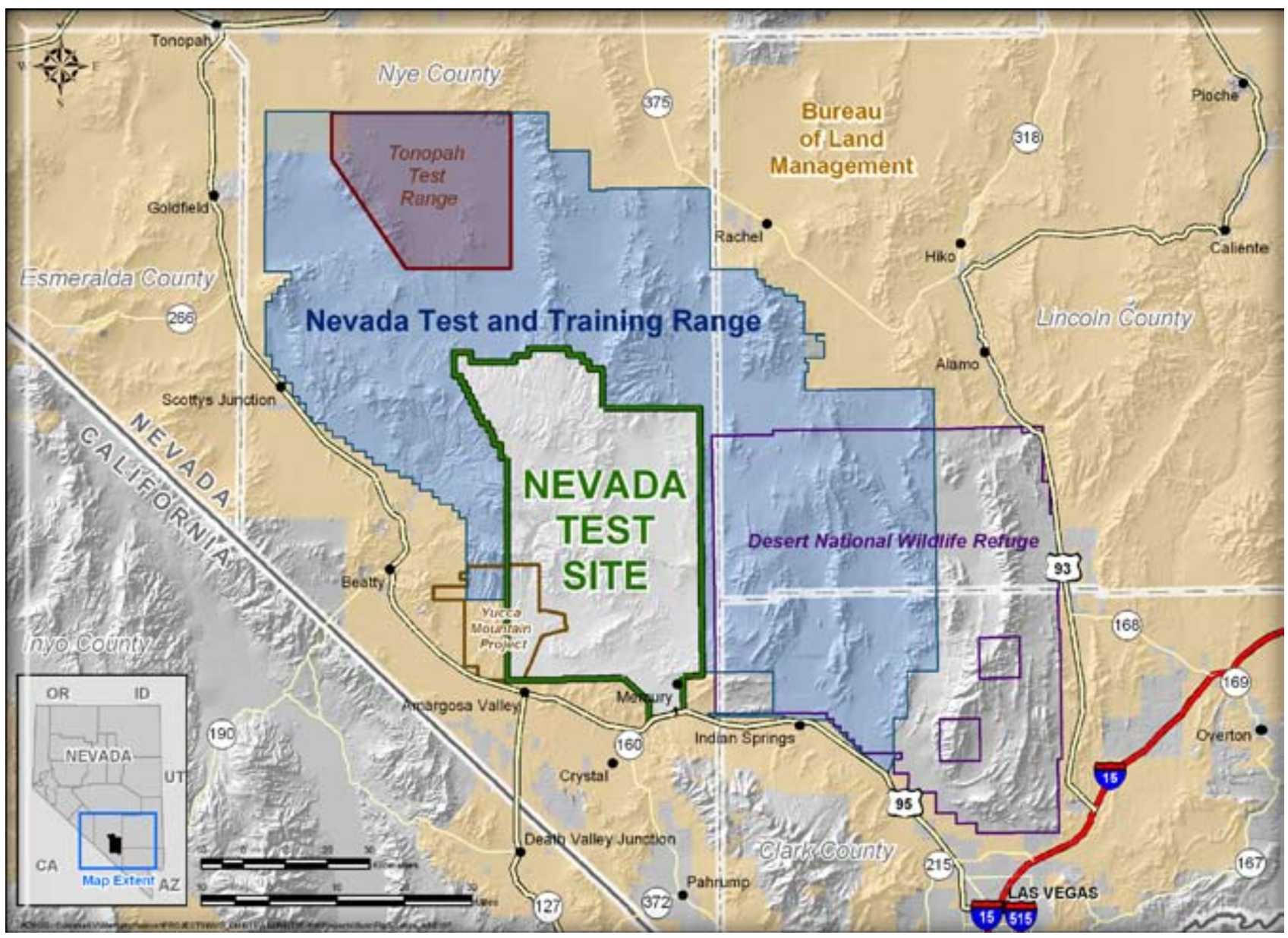




\section{NTS History}

Between 1940 and 1950, the area now known as the NTS was part of the Las Vegas Bombing and Gunnery Range. In 1950, the NTS was established as the primary location for testing the nation's nuclear explosive devices. Such testing took place from 1951 to 1992.

Tests conducted through the 1950s were predominantly atmospheric tests. These involved a nuclear explosive device detonated while on the ground surface, on a steel tower, suspended from tethered balloons, dropped from an aircraft, or placed on a rocket. Several tests were categorized as "safety experiments" and "storagetransportation tests," involving the destruction of a nuclear device with non-nuclear explosives. Some of these tests resulted in dispersion of plutonium in the test vicinity. One of these test areas, Project 57, lies just north of the NTS boundary on the Nevada Test and Training Range (NTTR). Other tests, involving storagetransportation, were conducted at the north end of the NTTR (Double Tracks) and on the Tonopah Test Range (TTR) (Clean Slates I, II, and III). All nuclear device tests are listed in United States Nuclear Tests, July 1945 through September 1992. ${ }^{1}$

The first underground test, a cratering test, was conducted in 1951. The first totally contained underground test was in 1957. Testing was discontinued during a moratorium that began October 31, 1958, but was resumed in September 1961 after tests by the Union of Soviet Socialist Republics began. Since late 1962, nearly all tests have been conducted in sealed vertical shafts drilled into Yucca Flat and Pahute Mesa or in horizontal tunnels mined into Rainier Mesa. From 1951 to 1992, a total of 828 underground nuclear tests were conducted at the NTS. Approximately one-third of these tests was detonated near or below the water table.

Five earth-cratering (shallow-burial) tests were conducted over the period of 1962 through 1968 as part of the Plowshare Program that explored peaceful uses of nuclear explosives. The first and highest yield Plowshare crater test, Sedan, was detonated at the northern end of Yucca Flat on the NTS. The second-highest yield crater test was Schooner, located in the northwest corner of the NTS. Mixed fission products, tritium, and plutonium from these tests were entrained in the soil, ejected from the craters, and deposited on the ground surrounding the craters.

Other nuclear-related experiments at the NTS included the Bare Reactor Experiment-Nevada series in the 1960s. These tests were performed with a 14-million electron volt neutron generator mounted on a 1,527-foot steel tower used to conduct neutron and gammaray interaction studies on various materials and assess radiation doses experienced by the nuclear bomb survivors of Hiroshima and Nagasaki. In addition, from 1959 through 1973 a series of open-air nuclear reactor, nuclear engine, and nuclear furnace tests were conducted in Area 25, and a series of tests with a nuclear ramjet engine was conducted in Area 26. The test released mostly gaseous radioactivity (radio-iodines, radio-xenons, radio-kryptons) and some fuel particles due to erosion of the metal cladding on the reactor fuel; these releases resulted in negligible deposition on the ground.

\section{NTS - Continental Test Site}

After the end of World War II, the United States tested nuclear weapons at Bikini Atoll and Enewetak in the Marshall Islands of the Central Pacific.

In June 1950, with the outbreak of hostilities in Korea and U.S. relations with the Soviet Union continuing to deteriorate, the search began for a continental test site to overcome the difficulties with remoteness and security experienced with testing in the Pacific. The final choices included Dugway Proving Ground-Wendover Bombing Range in western Utah, Alamagordo-White Sands Guided Missile Range in south central New Mexico, and a North Site and a South Site on the Las Vegas Bombing and Gunnery Range in southern Nevada.

On December 18, 1950, President Truman approved the recommendations of Los Alamos testing officials and the Atomic Energy Commission, christening the South Site on the Las Vegas Bombing and Gunnery Range as the nation's continental test site. It is called the Nevada Proving Ground.

On Saturday, January 27, 1951, an Air Force B-50D bomber dropped a 1-kiloton yield nuclear bomb over Frenchman Flat. It was the world's tenth nuclear detonation and was the first NTS test.

On September 23, 1992, the last underground nuclear test was conducted on the NTS after which Congress imposed a moratorium on nuclear weapons testing.

Since 1951, a total of 100 atmospheric and 828 underground nuclear weapons tests were conducted at the NTS.

Source: T. R. Fehner and F. G. Gosling, 2000. Origins of the Nevada Test Site, DOE/MA-0518, History Division, Executive Secretariat, Management and Administration, U.S. Department of Energy.

\footnotetext{
${ }^{1}$ U.S. Department of Energy, 2000. Report No. DOE/NV--209 (Rev. 15).
} 


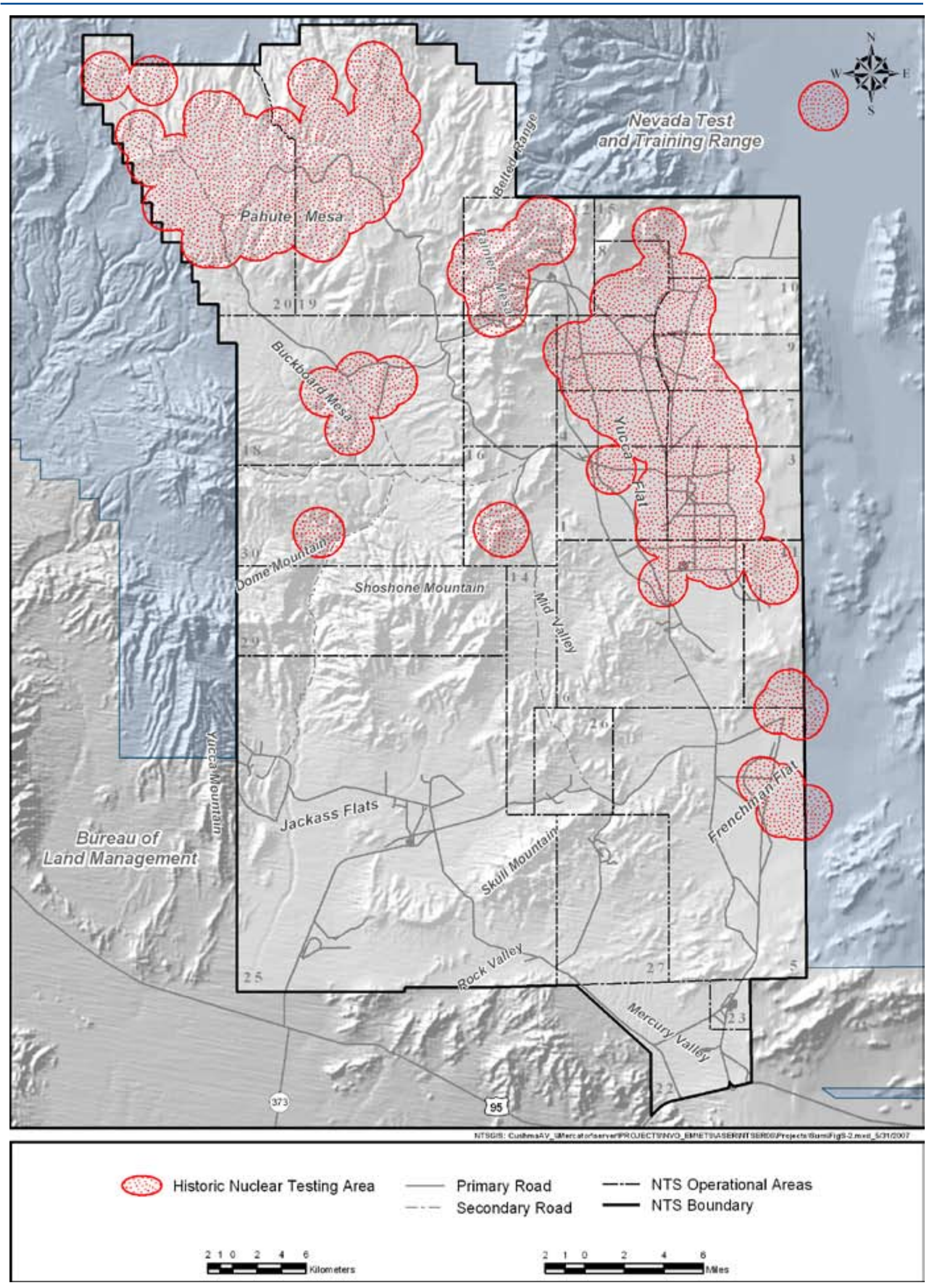

Historic Nuclear Testing Areas 


\section{The NTS Now}

Los Alamos, Lawrence Livermore, and Sandia National Laboratories are the principal organizations that sponsor and implement experimental programs at the NTS. The three major NTS missions include National Security, Environmental Management, and Stewardship of the NTS. During the conduct of all missions and their programs, NNSA/NSO complies with applicable environmental and public health protection regulations and strives to manage the land and facilities at the NTS as a unique and valuable national resource. In 2007, National Security Technologies, LLC (NSTec), was the Management and Operations contractor accountable for the successful execution of work and ensuring that work was performed in compliance with environmental regulations.

NTS activities in 2007 continued to be diverse, with the primary goal being to ensure that the existing U.S. stockpile of nuclear weapons remains safe and reliable. Facilities that support this mission include the U1a Facility, the Big Explosives Experimental Facility (BEEF), the Device Assembly Facility (DAF), and the Joint Actinide Shock Physics Experimental Research (JASPER) Facility. Facilities that support the Homeland Security program include the new Radiological/Nuclear Countermeasures Test and Evaluation Complex (Rad/NucCTEC), which was expected to be operational in October 2006, but is currently on hold. Facilities that support the Waste

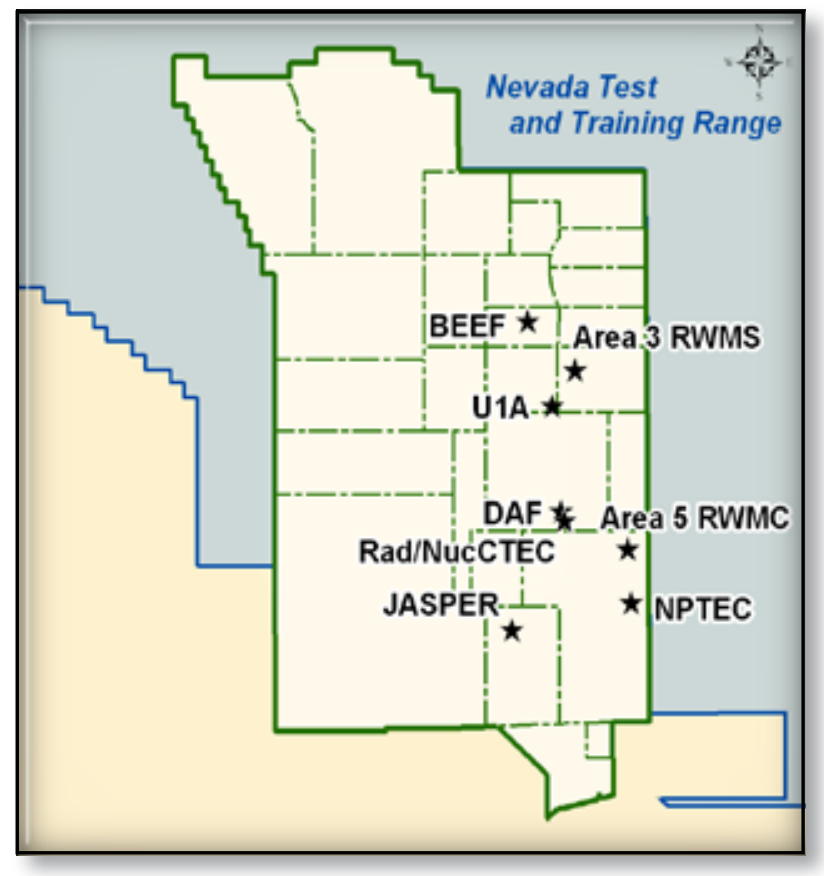

Management Program include the Area 5 Radioactive Waste Management Complex (RWMC) and the Area 3 Radioactive Waste Management Site (RWMS). Other NTS activities include demilitarization activities; controlled spills of hazardous material at the NonProliferation Test and Evaluation Complex (NPTEC) (formerly known as the Hazardous Materials Spill Center); remediation of industrial sites; processing of waste destined for the Waste Isolation Pilot Plant in Carlsbad, New Mexico, or the Idaho National Laboratory in Idaho Falls, Idaho; disposal of radioactive and mixed waste; and environmental research.

\section{NTS Missions and Their Programs}

\section{National Security}

Stockpile Stewardship Program - Conducts highhazard operations in support of defense-related nuclear and national security experiments.

Homeland Security Program - Provides support facilities, training facilities, and capabilities for government agencies involved in counterterrorism activities, emergency response, first responders, national security technology development, and nonproliferation technology development.

Test Readiness Program - Maintains the capability to resume underground nuclear weapons testing, if directed.

\section{Environmental Management}

Environmental Restoration Program - Characterizes and remediates the environmental legacy of nuclear weapons and other testing at the NTS and offsite locations and develops and deploys technologies that enhance environmental restoration.

Waste Management Program - Manages and safely disposes of low-level waste received from DOEand U.S. Department of Defense-approved facilities throughout the United States and mixed low-level waste generated in Nevada by NNSA/NSO, and safely manages and characterizes hazardous and transuranic wastes for offsite disposal.

\section{Stewardship of the NTS}

Facilities and Infrastructure - Maintains the buildings, roads, utilities, and facilities required to support all NTS programs and to provide a safe environment for NTS workers. 


\section{Legacy Contamination}

Groundwater - Areas of known and potential groundwater contamination on the NTS due to underground nuclear testing are called Underground Test Area (UGTA) Corrective Action Units. It is estimated that 300 million curies $(\mathrm{Ci})$ of radiation were released underground during 828 nuclear tests. The total amount of radiation deposited below the groundwater table is approximately 60 million $\mathrm{Ci}$, based on the last decay-corrected calculation from 1992. Since there is no feasible technology available that would allow for the cleanup of deep, extensive groundwater contamination, the strategy of the Environmental Management Program is to identify contaminant boundaries and implement an effective long-term monitoring system.

Soil - Radioactively contaminated surface soils directly resulting from nuclear weapons testing occur at approximately 100 sites on and around the NTS. Closure of these sites is conducted in accordance with the Federal Facility Agreement and Consent Order (FFACO) and upon approval of the State of Nevada. Corrective actions required to complete closure range from removal of soil to closure in place with restricted access controls, such as fencing and posting.

Air - Airborne radioactive contamination from the resuspension of contaminated soils at legacy sites and from current activities (such as waste management) is monitored continuously on and off the NTS. Since the cessation of atmospheric nuclear testing, the annual amounts of radiation released into the air from the NTS have ranged from 48 to 2,200 $\mathrm{Ci}$ for tritium, 0.0018 to $0.40 \mathrm{Ci}$ for plutonium, and 0.039 to $0.049 \mathrm{Ci}$ for americium. These emissions cannot be distinguished from the background airborne radiation measured in communities surrounding the NTS.

Structures/Materials - There are approximately 1,850 sites where facilities, equipment, structures, and/or debris were contaminated by historic nuclear research, development, and testing activities. The responsibility for remediating these Industrial Sites belongs to the Environmental Restoration Project. As of May 30, 2008, 1,717 sites have been approved for final completion in accordance with the FFACO and approved by the State of Nevada.

Waste Disposal - Low-level and mixed low-level radioactive waste have been generated by historic nuclear research, development and testing activities, and the resulting environmental cleanup activities. More than 1.33 million cubic yards of this waste have been safely disposed at the Area 3 and Area 5 Radioactive Waste Management Sites as of December 30, 2007. The estimated total amount of radioactivity at the time of disposal was 13.5 million $\mathrm{Ci}$. The radioactive content of the disposed waste decays over time at a varied rate depending on the radionuclide.
The Legacy of NTS Nuclear Testing

Approximately one-third of the 828 underground nuclear tests on the NTS were detonated near or below the water table resulting in the contamination of groundwater in some areas. In addition, the 100 atmospheric nuclear tests conducted on the NTS and numerous nuclear-related experiments resulted in the contamination of surface soils, materials, equipment, and structures, mainly on the NTS. The NNSA/NSO Environmental Management Mission was established to address this legacy of contamination. Within Environmental Management, the Environmental Restoration Project is responsible for remediating contaminated sites, and the Waste Management Project is responsible for safely managing and disposing radioactive waste.

The primary regulatory driver of the Environmental Restoration Project is the Federal Facility Agreement and Consent Order (FFACO) between the State of Nevada, DOE, and U.S. Department of Defense. The FFACO identifies Corrective Action Units (CAUs), which are groupings of Corrective Action Sites (CASs) that delineate and define areas of concern for contamination. Approximately 2,800 CASs have been identified, many of which have already been remediated and/or closed. The public is kept informed of Environmental Management activities through periodic newsletters, exhibits, and fact sheets, and Environmental Management provides the opportunity for public input via the Community Advisory Board consisting of 15-20 citizen volunteers from Nevada.

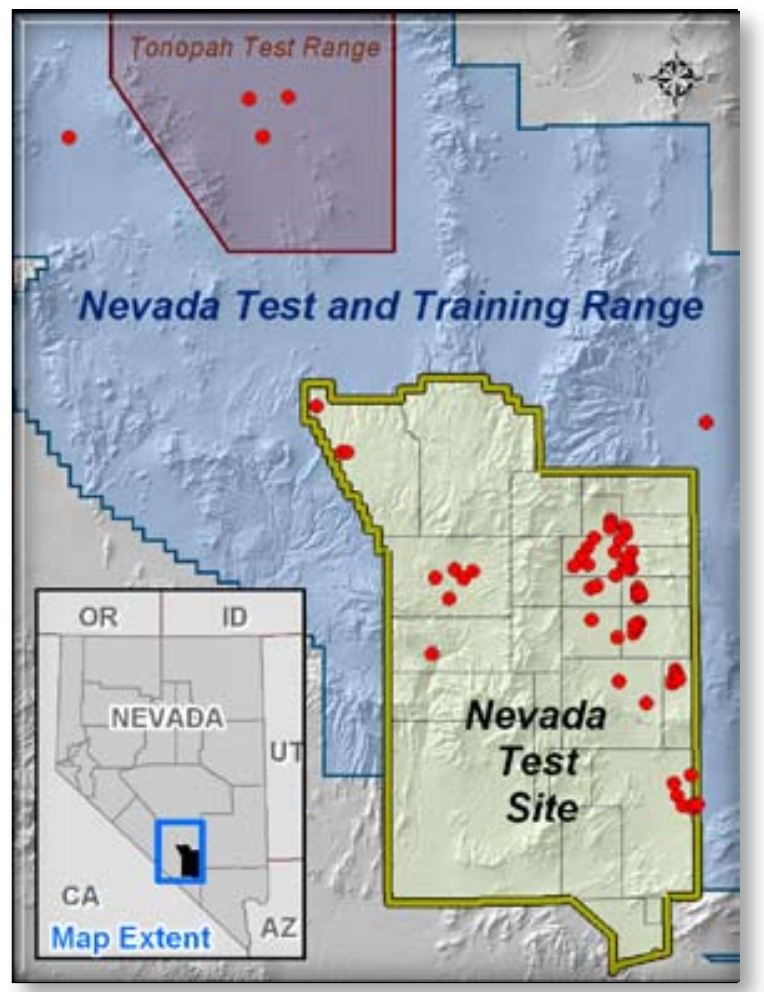

Areas of Soil Contamination on and off the NTS 


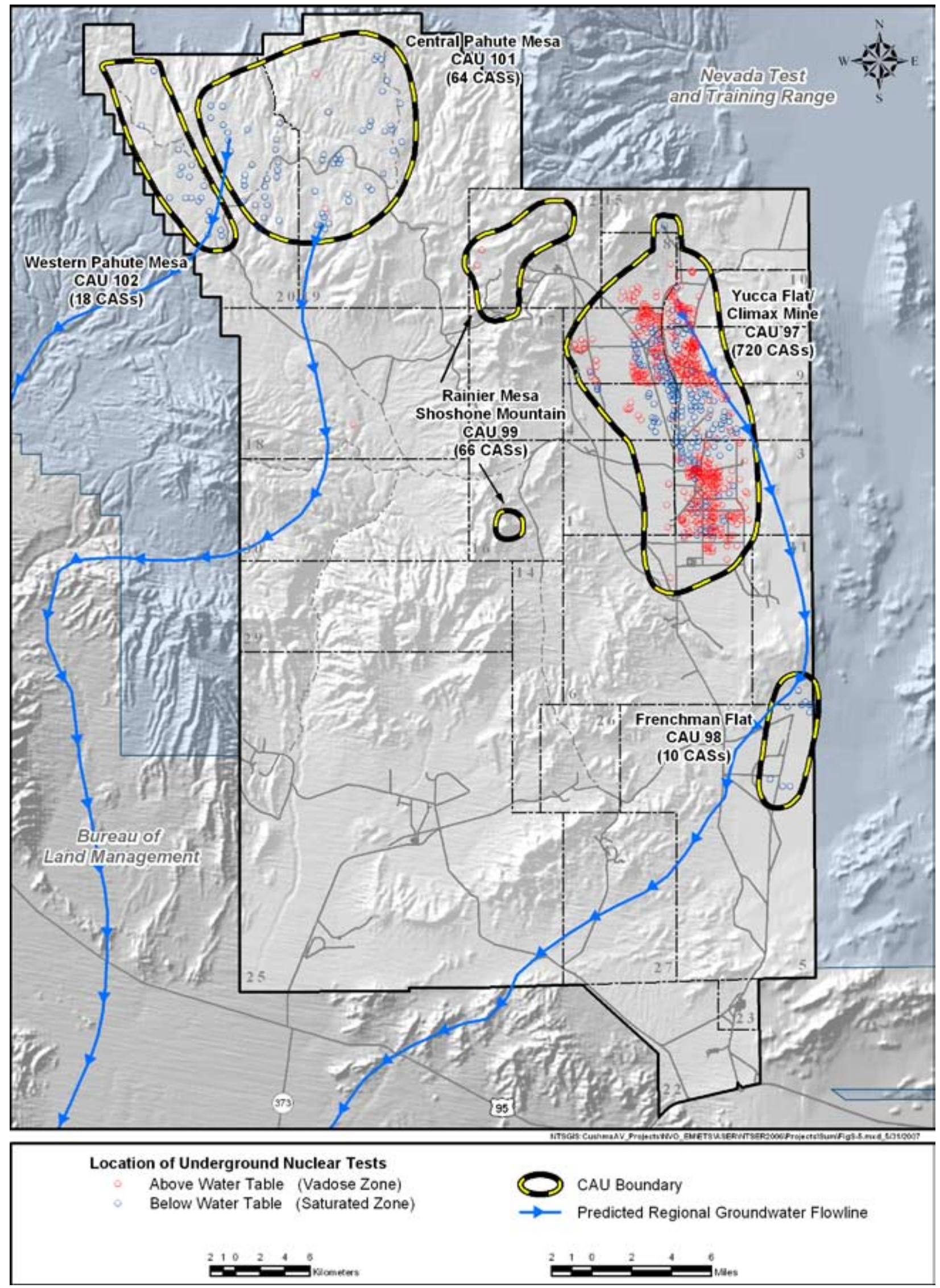




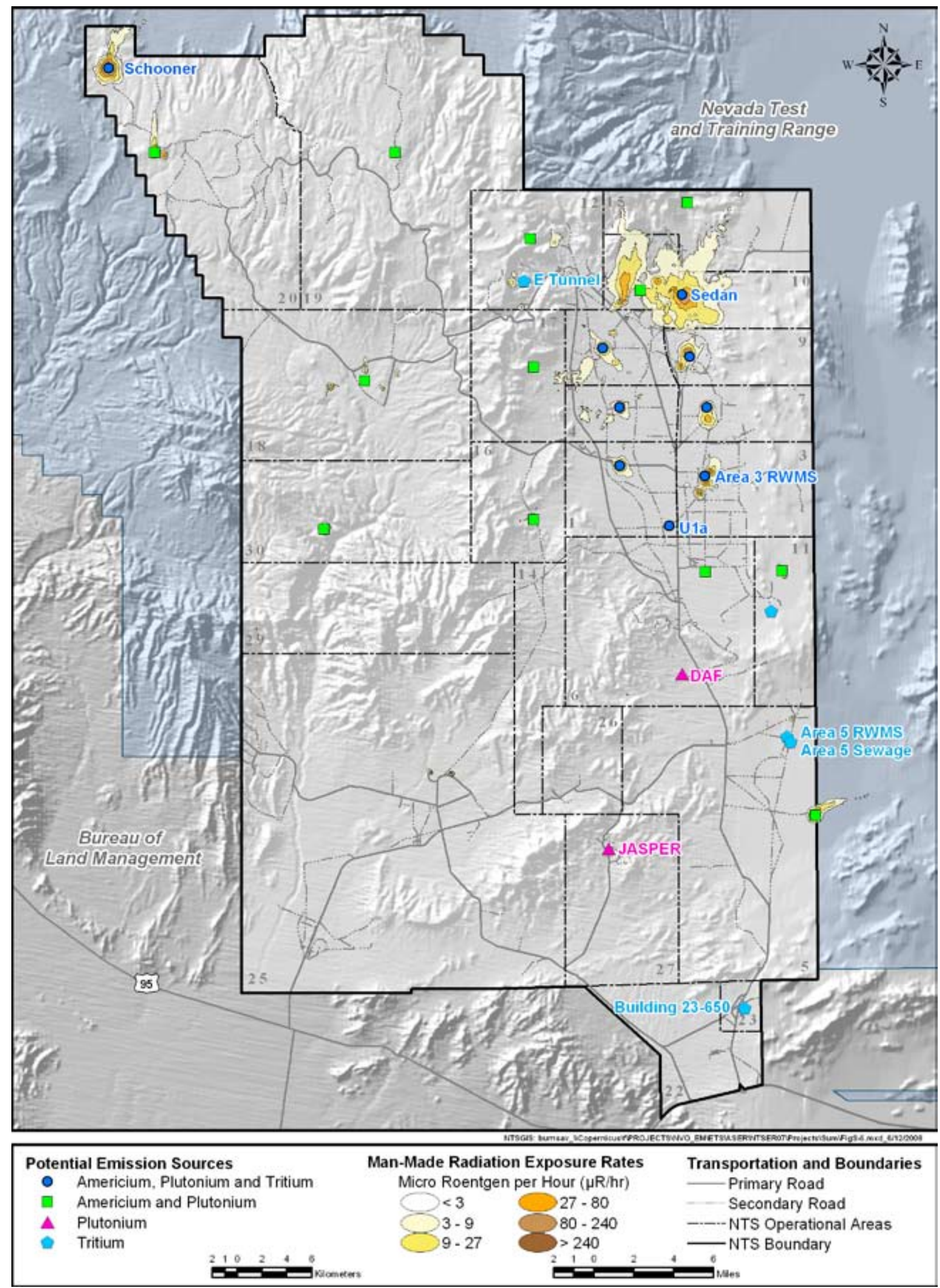

Potential Sources of Radiological Air Emissions on the NTS 


\section{Understanding Radiation}

Radiation is energy that travels through matter or space in the form of waves or high-speed particles. Light, heat, and sound are types of radiation. Ionizing radiation is a very high-energy form of electromagnetic radiation. Ionizing radiation are particles or rays given off by unstable atoms as they are converted, or decay, into more stable atoms. Ionizing radiation may be found everywhere. Almost all exposure to ionizing radiation comes from natural sources (82 percent in the United States). These sources include cosmic radiation from outer space, terrestrial radiation from materials like uranium and radium in the earth, and naturally occurring radioactive elements (i.e., radionuclides) in
Curie (Ci) is the traditional measure of radioactivity based on the observed decay rate of 1 gram of radium. One curie of radioactive material will have 37 billion disintegrations in 1 second.

our food, water, and the aerosols and gases in the air we breathe. Exposures to man-made radiation in our everyday life come from smoking cigarettes, traveling on airplanes, and having medical X-rays. For the public surrounding the NTS, less than 1 percent of their total radiation exposure is now attributable to past or current NTS activities.

\section{Forms of Radiation}

Alpha particles are heavy, positively charged particles given off by some decaying atoms. Alpha particles can be blocked by a sheet of paper. Atoms emitting alpha particles are hazardous only if they are swallowed or inhaled.

Beta particles are electrons or positrons (positively charged electrons) ejected from the nucleus of a decaying atom. More penetrating than alpha radiation, beta particles can pass through several millimeters of skin. A sheet of aluminum only a fraction of an inch thick will stop beta radiation. Beta particles can damage skin, but are most hazardous if the beta-emitting atoms are swallowed or inhaled.

Gamma rays are waves of pure energy similar to X-rays, light, microwaves, and radio waves. Gamma rays are emitted by certain radionuclides when their nuclei transition from a higher to a lower energy state. They can readily pass into the human body. They can be almost completely blocked by about 40 inches of concrete, 40 feet of water, or a few inches of lead. Gamma rays can be both an external and internal hazard.

X-rays are a more familiar form of electromagnetic radiation, usually with a limited penetrating power, typically used in medical or dental examinations. Television sets, especially color, give off soft (low-energy) $\mathrm{X}$-rays; thus, they are shielded to greatly reduce the risk of radiation exposure.

Neutrons are uncharged heavy particles contained in the nucleus of every atom heavier than ordinary hydrogen. They induce ionization only indirectly in atoms which they strike, but can damage body tissues. Neutrons are released, for example, during the fission (splitting) of uranium atoms in the fuel of nuclear power plants. They can also be very penetrating. In general, efficient shielding against neutrons can be provided by materials containing hydrogen, such as water. Like gamma rays, neutrons are both an external and internal hazard.

\section{Understanding Radiation Dose}

Dose is a generic term to describe the amount of radiation a person receives. The energy deposited indicates the number of molecules disrupted. The energy the radiation deposits in tissue is called the absorbed dose. The units of measure of absorbed dose are the rad or the gray. The biological effect of radiation depends on the type of radiation (alpha, beta, gamma, or X-ray) and the tissues exposed. A measure of the biologic risk of the energy deposited is the dose equivalent. The units of dose equivalent are called rems or sieverts. In this report, the term dose is used to mean dose equivalent measured in rems. A thousandth of a rem is called a millirem, abbreviated as mrem. An average person in the United States receives about 300 mrem each year from natural sources and an additional $60 \mathrm{mrem}$ from medical procedures, consumer products, and activities. Whether or not there is a "safe" radiation dose equivalent is a controversial subject. Because the topic has yet to be settled scientifically, regulators take a conservative approach and assume that there is no such thing as a 100 percent safe dose equivalent, and it is assumed that the risk of 


\begin{tabular}{|c|c|c|c|c|}
\hline \multicolumn{5}{|c|}{ Radionuclides Detected on the NTS } \\
\hline & Name $^{*}$ & Abbreviation & $\begin{array}{l}\text { Primary Type(s) of } \\
\text { Radiation }\end{array}$ & Major NTS Source \\
\hline \multirow{6}{*}{ 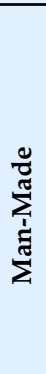 } & Americium-241 & ${ }^{241} \mathrm{Am}$ & Alpha, gamma ) & \multirow{4}{*}{$\begin{array}{l}\text { In soil at and near legacy sites of aboveground nuclear testing. } \\
\text { Detected in soil and air. }\end{array}$} \\
\hline & Cesium-137 & ${ }^{137} \mathrm{Cs}$ & Beta, gamma & \\
\hline & Plutonium-238 & ${ }^{238} \mathrm{Pu}$ & Alpha & \\
\hline & Strontium-90 & ${ }^{90} \mathrm{Sr}$ & Beta & \\
\hline & $\begin{array}{l}\text { Plutonium- } \\
239+240\end{array}$ & ${ }^{239+240} \mathrm{Pu}$ & Alpha & \multirow{2}{*}{$\begin{array}{l}\text { In soil at and near legacy sites of plutonium dispersal experiments. } \\
\text { Detected in soil and air. } \\
\text { In groundwater in areas of underground nuclear tests, in surface } \\
\text { ponds used to contain contaminated groundwater, in soil at nuclear } \\
\text { test locations, in waste packages buried in pits at waste management } \\
\text { sites. Detected in groundwater and air. }\end{array}$} \\
\hline & Tritium & ${ }^{3} \mathrm{H}$ & Beta & \\
\hline \multirow{7}{*}{ 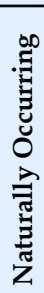 } & Be-7 & ${ }^{7} \mathrm{Be}$ & Gamma & $\begin{array}{l}\text { Produced by interactions between cosmic radiation from the sun and } \\
\text { the earth's upper atmosphere. Detected in air. }\end{array}$ \\
\hline & Potasium-40 & ${ }^{40} \mathrm{~K}$ & Beta, gamma & \multirow{6}{*}{$\begin{array}{l}\text { Naturally occurring in the earth's crust. Detected in groundwater, } \\
\text { soil, and air. }\end{array}$} \\
\hline & Radium-226 & ${ }^{226} \mathrm{Ra}$ & Alpha, gamma & \\
\hline & Thorium-232 & ${ }^{232} \mathrm{Th}$ & Alpha** & \\
\hline & Uranium-234 & ${ }^{234} \mathrm{U}$ & Alpha** & \\
\hline & Uranium-235 & ${ }^{235} \mathrm{U}$ & Alpha, gamma** & \\
\hline & Uranium-238 & ${ }^{238} \mathrm{U}$ & Alpha $^{* *}$ & \\
\hline \multicolumn{5}{|c|}{$\begin{array}{l}\text { *The number given with the name of the radionuclide is the atomic mass number and is the number of protons and neutrons together in the nucleus of the atom. } \\
\text { Radionuclides with the same number of protons are the same element and radionuclides of the same element are called isotopes of one another. Plutonium and uranium } \\
\text { each have several radioactive isotopes that are detected on the NTS. }\end{array}$} \\
\hline
\end{tabular}

developing an adverse health effect (such as cancer) is proportionate to the amount of radiation dose. Many human activities increase our exposure to radiation over and above the average background radiation dose of 300 mrem per year. These activities include, for example, uranium mining, airline travel, and operating nuclear power plants. Regulators balance the benefit of these activities to the risk of increasing radiation exposures above background, and as a result, set dose limits for the public and workers specific to these activities. The DOE has set the dose limit to the public from exposure to DOE-related nuclear activities to $100 \mathrm{mrem} / \mathrm{yr}$. This is the same public dose limit set by the U.S. Nuclear Regulatory Commission (NRC) and recommended by the International Commission on Radiological Protection and the National Commission on Radiological Protection and Measurements. The NRC has set the dose limit for radiation workers to $5 \mathrm{rem} / \mathrm{yr}$. There is no regulatory standard for radiation dose limits to workers or the public across industries, states, or countries.

\begin{tabular}{|ll|}
\hline \multicolumn{2}{|c|}{ Common Doses to the Public } \\
\hline \multicolumn{1}{|c|}{ Source/Activity } & \multicolumn{1}{c|}{$\begin{array}{c}\text { Average Dose/Year } \\
\text { (or as noted) }\end{array}$} \\
\hline Five-hour jet plane ride & $3 \mathrm{mrem}$ \\
Building materials & $4 \mathrm{mrem}$ \\
Chest X-ray & $8 \mathrm{mrem}$ \\
Cosmic & $30 \mathrm{mrem}$ \\
Soil & $35 \mathrm{mrem}$ \\
Internal to our body & $40 \mathrm{mrem}$ \\
Mammogram & $138 \mathrm{mrem}$ \\
Radon gas & $200 \mathrm{mrem}$ \\
CT scan & $2,500 \mathrm{mrem}$ \\
Smoking 20 cigarettes/day & $5,300 \mathrm{mrem}$ to a smoker's lung \\
One cancer treatment & $5,000,000$ mrem to the tumor \\
\hline $\begin{array}{l}\text { Source: <http://hssenergy.gov/HealthSafety/WSHP/radiation/Radiation-final-6-20.pdf>, } \\
\text { accessed on 6/26/2008 }\end{array}$ \\
\hline
\end{tabular}




\section{Monitoring NTS Radiation and Pathways of Exposure to the Public}

The release of man-made radionuclides from the NTS has been monitored since the first decade of atmospheric testing. After 1962 when nuclear tests were conducted only underground, the radiation exposure to the public surrounding the NTS was greatly reduced. Underground nuclear testing nearly eliminated atmospheric releases of radiation, but resulted in the contamination of groundwater in some areas of the NTS. After the 1992 moratorium on nuclear testing, radiation monitoring focused on detecting airborne radionuclides that are resuspended with historically contaminated soils on the NTS and on detecting man-made radionuclides in groundwater.

There are three pathways in this dry desert environment by which man-made radionuclides from the NTS might reach the surrounding public:

\section{Air Transport}

Pathway - Members of the public may inhale or ingest radionuclides that are resuspended by the wind from known contaminated sites on the NTS. However, such resuspended radiation measured off and on the NTS is much lower than natural background radiation in all areas accessible to the public.

Ingestion Pathway - Members of the public may ingest game animals that have been exposed to contaminated soil or water on the NTS, have moved off the NTS, and have then been hunted.

Groundwater Pathway - Drinking contaminated groundwater is currently not a possible pathway for public exposure given the restricted public access to the NTS and the location of known contaminated groundwater on the NTS. No man-made radionuclides occur in drinking water sources monitored off the NTS, and no drinking water wells on the NTS have measurable levels of man-made radionuclides. Only the groundwater from monitoring wells drilled near underground tests on the NTS show radioactive contamination. 


\section{Estimated 2007 Radiation Dose to the Public from NTS Operations}

Inhalation - Compliance with radiation dose limits to the general public from the air transport pathway is demonstrated using air sampling results from six onsite "critical receptor" sampling stations. The radionuclides detected at three or more of the NTS critical receptor samplers were ${ }^{241} \mathrm{Am},{ }^{238} \mathrm{Pu},{ }^{239+240} \mathrm{Pu},{ }^{233+234} \mathrm{U},{ }^{235+236} \mathrm{U}$, ${ }^{238} \mathrm{U}$, and ${ }^{3} \mathrm{H}$. The uranium isotopes are attributed to naturally occurring uranium. As in previous years, the 2007 data from the six critical receptor samplers show that the NESHAP dose limit to the public of $10 \mathrm{mrem} / \mathrm{yr}$ was not exceeded. The Schooner critical receptor station, in the far northwest corner of the NTS, had the highest concentrations of radioactive air emissions, yet an individual residing at this station would experience a dose from air emissions of only $1.9 \mathrm{mrem} / \mathrm{yr}$. This annual dose is 19 percent of the NESHAP public dose limit. No one resides at this location, and the dose at offsite populated locations (12 to 50 miles) from the Schooner station would be much lower due to wind dispersion.

Ingestion - NTS game animals include pronghorn antelope, mule deer, chukar, Gambel's quail, mourning doves, cottontail rabbits, and jackrabbits. Small game animals from different contaminated NTS sites are trapped each year and analyzed for their radionuclide content. These results are used to construct worst-case scenarios for the dose to hunters who might consume these animals if the animals moved off the NTS. In 2007, mourning doves were sampled at the E Tunnel Ponds. The muscle tissues of a pronghorn antelope killed accidentally by a vehicle and of a foal (used as a surrogate large game animal) killed by a predator were also sampled in 2007. Based on these samples, the highest dose to a member of the public was estimated to be $0.091 \mathrm{mrem}$ for the person who consumed the entire sampled antelope.

Direct Exposure - No members of the public are expected to receive direct gamma radiation from NTS operations which is above background levels. Areas accessible to the public, such as the main entrance gate,
Croundwater - there is no NTS

Gradiation dose to the public from this pathway. Annual monitoring continues to verify that no contaminated groundwater has migrated beyond the NTS boundaries into surrounding water supplies used by the public had direct gamma radiation exposure rates comparable to natural background rates from cosmic and terrestrial radiation. A very small exposure to external radiation from a piece of heavy equipment taken off of the NTS may have occurred in 2007. A shear machine used for demolition projects that contained residual radioactive material was taken off of the NTS for 112 days in 2007. The estimated maximum dose to a hypothetical individual who spent 12 hours per day within 1 foot of the radioactive material for all 112 days is less than $0.2 \mathrm{mrem}$. This estimate is extremely conservative (i.e., greater than expected), because it is also assumed that the hypothetical individual ingested all the removable radioactive material that was on the equipment.

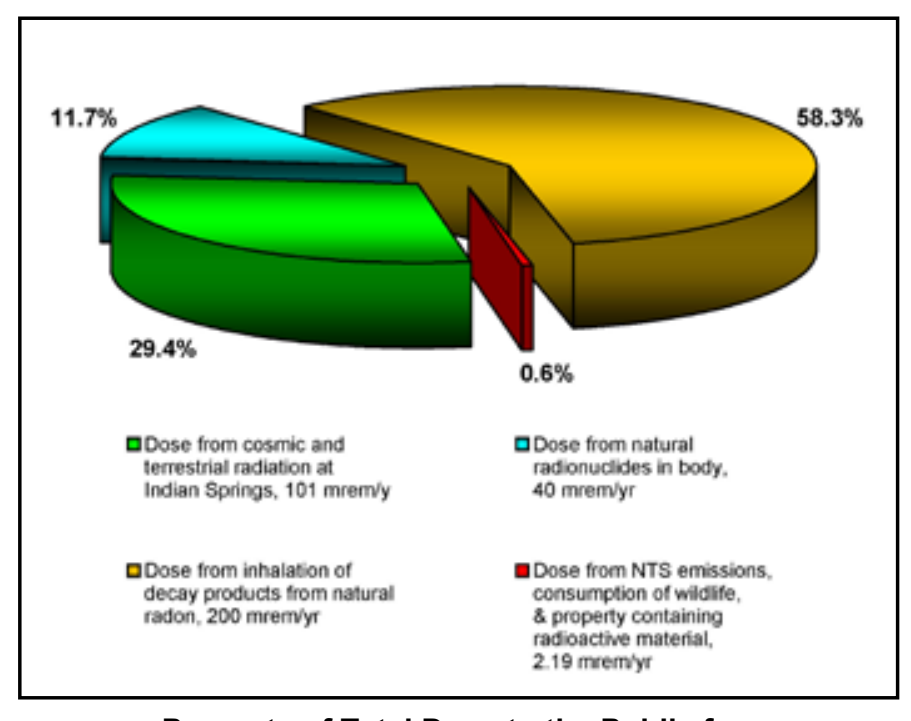

Percents of Total Dose to the Public from Natural Background Sources and from the NTS

\section{Dose to the Public from All Pathways}

$2.19 \mathrm{mrem} / \mathrm{yr}$ - This is the maximum dose to the public from inhalation, ingestion, and direct exposure pathways that is attributable to NTS operations. It is well below the dose limit of $100 \mathrm{mrem} / \mathrm{yr}$ established by DOE Order 5400.5 for radiation exposure to the public from all pathways combined. This total dose estimate is indistinguishable from natural background radiation experienced by the public residing in communities surrounding the NTS. 


\section{Radioactive Air Emissions}

NTS radioactive emissions are monitored on site to determine the public dose from inhalation (presented on page 11) and to ensure compliance with NESHAP under the Clean Air Act. A network of 19 air sampling stations and a network of 109 thermoluminescent dosimeters (TLDs) are located throughout the NTS (see map on page 13), mainly within those numbered Operational Areas where historic nuclear testing has occurred or where current radiological operations occur. NTS air sampling stations monitor tritium in water vapor, man-made radionuclides, and gross alpha and beta radioactivity in airborne particulates. The TLD stations monitor direct gamma radiation esposure.

\section{Concentration of Man-Made Radionuclides -}

Several man-made radionuclides were detected at NTS air sampling stations in 2007: ${ }^{241} \mathrm{Am},{ }^{3} \mathrm{H},{ }^{238} \mathrm{Pu}$, and ${ }^{239+240} \mathrm{Pu}$. None, however, exceeded concentration limits established by the Clean Air Act. The highest average level of ${ }^{241} \mathrm{Am},{ }^{238} \mathrm{Pu}$, and ${ }^{239+240} \mathrm{Pu}$ was detected at Bunker 9-300 in Area 9, located within an area of known soil contamination from past nuclear tests. The highest average level of tritium was detected at Schooner, site of the second-highest yield Plowshare cratering experiment on the NTS where tritium-infused ejecta surrounds the crater.

No man-made radionuclides were detected above minimum detectable concentrations in the air samples from the JASPER Facility, and no radiological releases occurred at U1a, BEEF, or DAF. Man-Made Radionuclides in Air Samples on the NTS

\begin{tabular}{|c|c|c|c|}
\hline \multicolumn{4}{|c|}{$\begin{array}{l}\text { Highest Average Concentrations of } \\
\text { Man-Made Radionuclides in Air Samples on the NTS }\end{array}$} \\
\hline Radionuclide & $\begin{array}{c}C L^{(a)} \\
\left(10^{-15} \mu \mathrm{Ci} / \mathrm{mL}\right)\end{array}$ & $\begin{array}{l}\text { Highest Average } \\
\text { Concentration } \\
\left(10^{-15} \mu \mathrm{Ci} / \mathrm{mL}\right)^{(\mathbf{b})}\end{array}$ & $\begin{array}{l}\text { Sampler } \\
\text { Location }\end{array}$ \\
\hline${ }^{241} \mathrm{Am}$ & 1.9 & 0.046 & Bunker 9-300 \\
\hline${ }^{3} \mathrm{H}$ & $1,500,000$ & 285,320 & Schooner \\
\hline${ }^{238} \mathrm{Pu}$ & 2.1 & 0.0053 & Bunker 9-300 \\
\hline${ }^{239+240} \mathrm{Pu}$ & 2.0 & 0.279 & Bunker 9-300 \\
\hline \multicolumn{4}{|c|}{$\begin{array}{l}\text { (a) Concentration limits established by NESHAP, in microcuries per milliliter }(\mu \mathrm{Ci} / \mathrm{mL}) \text {. } \\
\text { (b) The scale of concentration units for radionuclides shown in the table have been } \\
\text { standardized to } 10^{-15} \mu \mathrm{Ci} / \mathrm{mL} \text {. This scale may differ from those reported in detailed } \\
\text { radionuclide-specific data tables in the NTSER. }\end{array}$} \\
\hline
\end{tabular}

(a) Concentration limits established by NESHAP, in microcuries per milliliter $(\mu \mathrm{Ci} / \mathrm{mL})$.

(b) The scale of concentration units for radionuclides shown in the table have been standardized to $10^{-15} \mu \mathrm{Ci} / \mathrm{mL}$. This scale may differ from those reported in detailed radionuclide-specific data tables in the NTSER.

Radioactive emissions are also monitored at stations in selected towns and communities within 240 miles of the NTS by the independent Community Environmental Monitoring Program (CEMP), which is coordinated by the Desert Research Institute (DRI) of the Nevada System of Higher Education under contract with NNSA/NSO. The CEMP can independently confirm NTS's compliance with radiological air emission standards. Its purpose is to provide monitoring for radionuclides which may be released from the NTS. A network of 29 CEMP stations are used (see map on page 14). The CEMP stations monitor gross alpha and beta radioactivity in airborne particulates using low-volume particulate air samplers, penetrating gamma radiation using TLDs, gamma radiation exposure rates using pressurized ion chamber (PIC) detectors, and meteorological parameters using automated weather instrumentation (MET stations). made radionuclides that were emitted to the air from all sources on the NTS in 2007 was estimated to be $550 \mathrm{Ci}$ for tritium, $0.047 \mathrm{Ci}$ for ${ }^{241} \mathrm{Am}, 0.054 \mathrm{Ci}$ for ${ }^{238} \mathrm{Pu}$, and $0.32 \mathrm{Ci}$ for ${ }^{239+240} \mathrm{Pu}$. These amounts are similar to those from previous years. Over the past 10 years, total emissions have ranged from 160 to $564 \mathrm{Ci}$ for tritium, 0.039 to $0.049 \mathrm{Ci}$ for americium, and 0.24 to $0.39 \mathrm{Ci}$ for ${ }^{239+240} \mathrm{Pu}$.

No airborne radioactivity related to any NTS operations was detected in any of the CEMP samples during 2007. No man-made gamma-emitting radionuclides were detected. Naturally occurring radioactive beryllium $(\mathrm{Be})$ was detected in most air particulate samples.

\section{amounts (measured in Ci) of man- \\ Total Quantity of Man-Made Radionuclides - The total}

\begin{tabular}{|c|c|c|c|}
\hline \multicolumn{4}{|c|}{$\begin{array}{c}\text { Estimated Quantity of Man-Made Radionuclides } \\
\text { Released into the Air from the NTS in } 2007 \\
\text { (in Curies) }\end{array}$} \\
\hline $\begin{array}{l}\text { Tritium } \\
\quad\left({ }^{3} \mathrm{H}\right)\end{array}$ & $\begin{array}{l}\text { Plutonium } \\
\quad\left({ }^{238} \mathrm{Pu}\right)\end{array}$ & $\begin{array}{l}\text { Plutonium } \\
\left({ }^{239+240} \mathrm{Pu}\right)\end{array}$ & $\begin{array}{l}\text { Americium } \\
\left({ }^{241} \mathrm{Am}\right)\end{array}$ \\
\hline 550 & 0.054 & 0.32 & 0.047 \\
\hline \multicolumn{4}{|c|}{$\begin{array}{l}\text { Plutonium and americium sources are legacy sites of past nuclear testing on the NTS where } \\
\text { these radionuclides are in surface soils that can become re-suspended by wind. }\end{array}$} \\
\hline
\end{tabular}




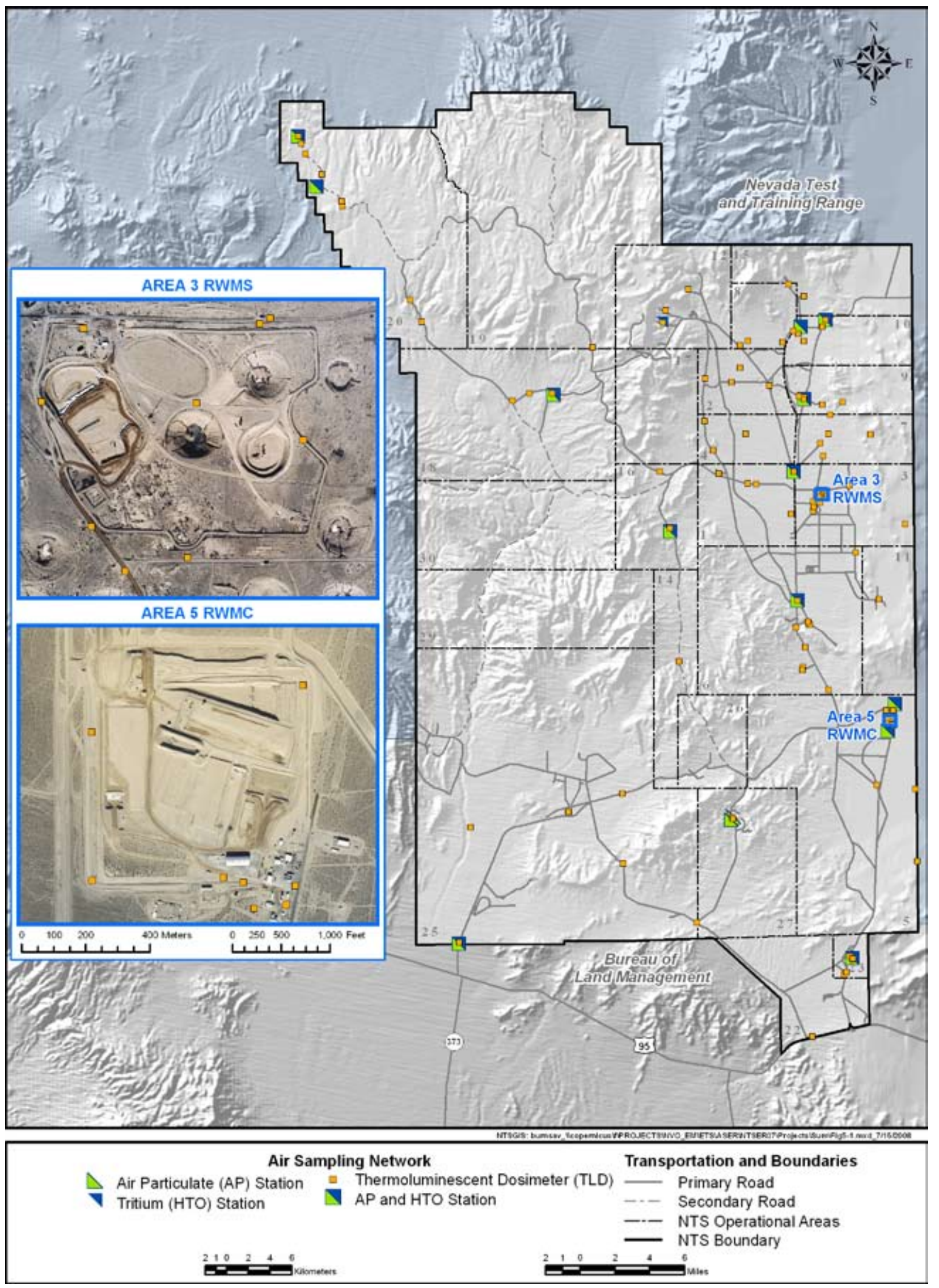

2007 NTS Air Sampling Network 


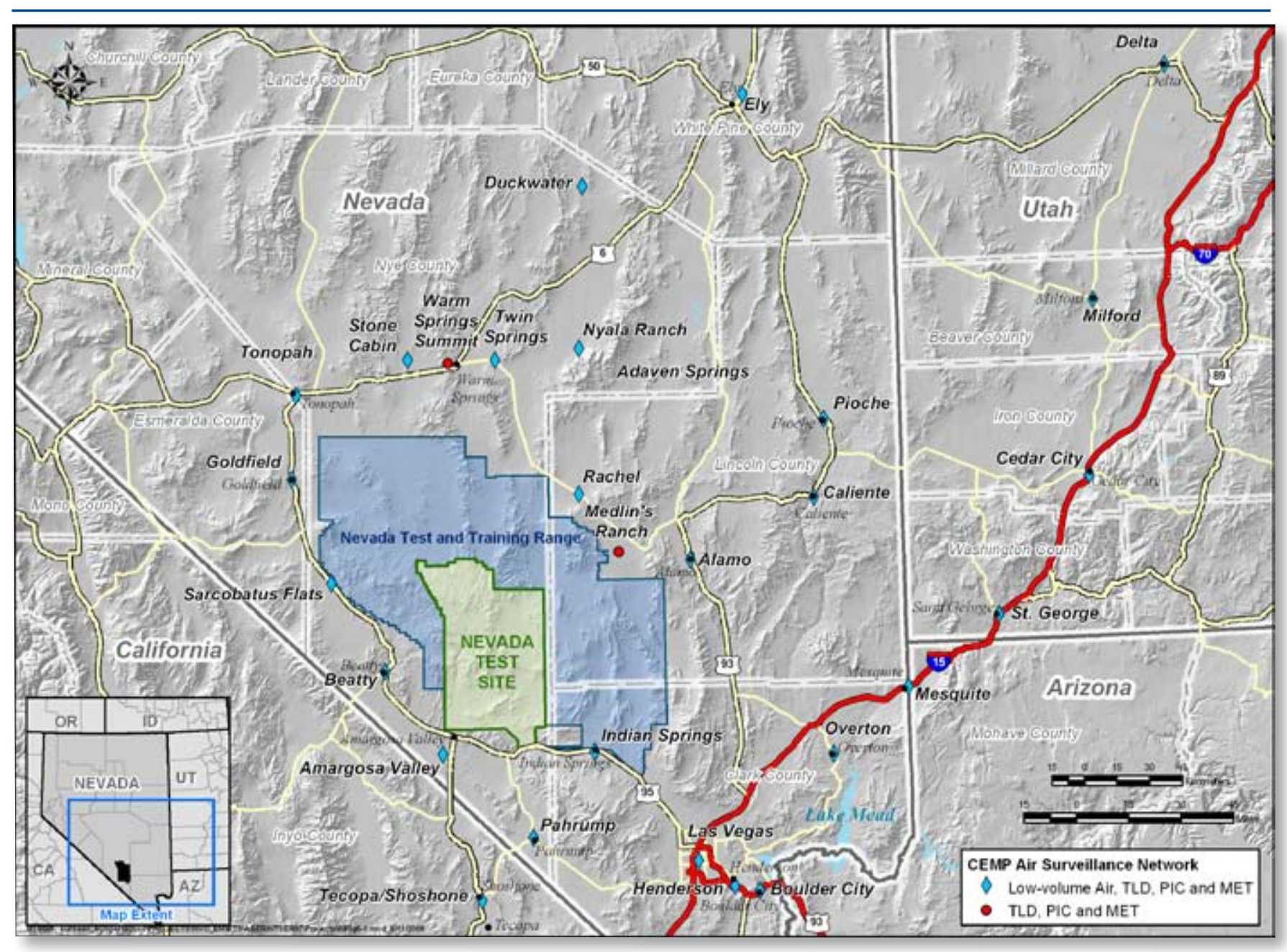

2007 CEMP Air Surveillance Network

Gamma Radiation Exposure - Ten of the NTS

TLD stations are located where radiation effects from NTS operations are negligible, and therefore measure only natural background levels of gamma radiation from cosmic and terrestrial sources. In 2007, the mean measured background level from the ten stations was $121 \mathrm{mR} / \mathrm{yr}$. This is well within average background levels observed in other parts of the U.S. of similar elevation above sea level. Background radiation varies not only by elevation but by the amounts of natural radioactive materials in soil and rock in different geographic regions.

The highest estimated mean annual gamma exposure measured at a TLD station on the NTS was $750 \mathrm{mR} / \mathrm{yr}$ at Schooner, one of the legacy Plowshare sites on Pahute Mesa. The lowest was $61 \mathrm{mR} / \mathrm{yr}$ in Mercury at the fitness track. The mean annual gamma exposure at 17 TLD locations near the Area 3 and Area 5 RWMSs was $147 \mathrm{mR}$. At the 35 TLD locations near known legacy sites (including Schooner), it was $267 \mathrm{mR}$.

The offsite TLD and PIC results remained consistent with previous years' background radiation levels and

\section{Direct exposure to gamma radiation is measured at 109 TLD stations on the NTS.}

Exposure is reported in units called milliroentgens $(m R)$.

Generally, a $1 \mathrm{mR}$ gamma exposure from the most common external radionuclides produces a 1 mrem dose.

are well within average background levels observed in other parts of the U.S. and with the $121 \mathrm{mR} / \mathrm{yr}$ level measured on the NTS. The highest total annual gamma exposure measured off site, based on the PIC detectors, was $183.96 \mathrm{mR} / \mathrm{yr}$ at Milford, Utah (at 4,957 feet elevation). The lowest offsite rate, based on the PIC detectors, was 58.87 $\mathrm{mR} / \mathrm{yr}$ at Pahrump, Nevada (at 2,675 feet elevation).

\section{NTS Background Gamma Radiation}

$121 \mathrm{mR} / \mathrm{yr}$ - This is the background radiation measured at 10 TLD stations in areas isolated from past and present nuclear activities. 
Average Direct Radiation Measured in 2007

\begin{tabular}{|lcc|}
\hline \multicolumn{1}{|c|}{ Location } & $\begin{array}{c}\text { Elevation } \\
\text { Above Sea } \\
\text { Level (feet) }\end{array}$ & $\begin{array}{c}\text { Radiation } \\
\text { Exposure } \\
\text { (mR/yr) }\end{array}$ \\
\hline NTS - Schooner TLD station & 5,660 & 750 \\
NTS - 35 Legacy Site TLD stations & $3,077-5,938$ & 267 \\
Warm Springs Summit, Nevada CEMP PIC station & 6,290 & 176 \\
Twin Springs, Nevada PIC station & 5,055 & 170 \\
NTS - 17 Waste Operation TLD stations & $3,176-4,021$ & 147 \\
NTS - 10 Background TLD stations & $2,755-5,938$ & 121 \\
St. George, Utah PIC station & 2,600 & 81 \\
Pahrump, Nevada PIC station & 2,550 & 72 \\
NTS Mercury Fitness Track TLD station & 3,769 & 61 \\
\hline
\end{tabular}

\section{Average Background Radiation of Selected U.S. Cities (Excluding Radon)}

\begin{tabular}{|lcc|}
\hline \multicolumn{1}{|c}{ City } & $\begin{array}{c}\text { Elevation Above } \\
\text { Sea Level } \\
\text { (feet) }\end{array}$ & $\begin{array}{c}\text { Radiation } \\
\text { Exposure } \\
\text { (mR/yr) }\end{array}$ \\
\hline Denver, Colorado & 5,280 & 164.6 \\
Wheeling, West Virginia & 656 & 111.9 \\
Rochester, New York & 505 & 88.1 \\
St. Louis, Missouri & 465 & 87.9 \\
Portland, Oregon & 39 & 86.7 \\
Los Angeles, California & 292 & 73.6 \\
Fort Worth, Texas & 650 & 68.7 \\
Richmond, Virginia & 210 & 64.1 \\
Tampa, Florida & 3 & 63.7 \\
New Orleans, Louisiana & 0 & 63.7 \\
\hline (a) Source: <http://www.wrcc.dri.edu/cemp/Radiation.html> \\
"Radiation in Perspective," August 1990, as accessed on 7/28/2008 \\
\hline
\end{tabular}

\begin{tabular}{|c|c|c|c|c|}
\hline \multicolumn{5}{|c|}{$\begin{array}{l}\text { Range in Radioactivity/Radiation Levels } \\
\text { Measured at Offsite and Onsite Air Sampling Stations }\end{array}$} \\
\hline & \multicolumn{2}{|c|}{$\begin{array}{l}\text { Average Gross Alpha } \\
\qquad\left(\times 10^{-15} \mu \mathrm{Ci} / \mathrm{mL}\right)\end{array}$} & \multicolumn{2}{|c|}{$\begin{array}{l}\text { Average Gross Beta } \\
\left(\times 10^{-14} \mu \mathrm{Ci} / \mathrm{mL}\right)\end{array}$} \\
\hline & $\begin{array}{l}\text { Offsite } \\
\text { (CEMP) }\end{array}$ & $\begin{array}{l}\text { Onsite } \\
\text { (NSTec) }\end{array}$ & $\begin{array}{l}\text { Offsite } \\
\text { (CEMP) }\end{array}$ & $\begin{array}{c}\text { Onsite } \\
\text { (NSTec) }\end{array}$ \\
\hline $\begin{array}{l}\text { Highest } \\
\text { Average } \\
\text { Value }\end{array}$ & $\begin{array}{l}2.75 \\
(\text { Las Vegas })\end{array}$ & $\begin{array}{l}3.00 \\
\text { (Bunker 9-300) }\end{array}$ & $\begin{array}{c}2.66 \\
\text { (Mesquite) }\end{array}$ & $\begin{array}{c}2.32 \\
\text { (Sugar Bunker) }\end{array}$ \\
\hline $\begin{array}{l}\text { Lowest } \\
\text { Average } \\
\text { Value }\end{array}$ & $\begin{array}{c}0.98 \\
(\text { Nyala Ranch) }\end{array}$ & $\begin{array}{c}1.48 \\
(\text { Gate } 20-2 P)\end{array}$ & $\begin{array}{l}1.95 \\
(\text { Nyala Ranch) }\end{array}$ & $\begin{array}{c}1.99 \\
\text { (Little Feller 2N) }\end{array}$ \\
\hline
\end{tabular}

\section{Gross Alpha and Beta}

Radioactivity - Gross alpha and gross beta radioactivity was detected at all NTS and CEMP stations at levels consistent with previous years. Levels of gross alpha and gross beta at all stations reflect radioactivity primarily from naturally occurring radioactive materials.

\section{Nonradioactive Air Emissions}

The release of air pollutants is regulated on the NTS under a Class II air quality operating permit. Class II permits are issued for "minor" sources where annual emissions must not exceed 100 tons of any one criteria pollutant, or 10 tons of any one of the 189 hazardous air pollutants (HAPs), or 25 tons of any combination of HAPs. Common sources of such air pollutants on the NTS include particulates from construction, aggregate production, surface disturbances, fugitive dust from driving on unpaved roads, fuel-burning equipment, open burning, fuel storage facilities, and chemical release tests conducted at the NPTEC on Frenchman Flat playa in Area 5.

\section{Estimated Quantity of Pollutants Released} into the Air from NTS Operations in 2007

\begin{tabular}{|lc|}
\hline \multicolumn{1}{|c|}{ Category } & Tons \\
\hline Criteria Air Pollutants: & \\
Particulate Matter (PM10)(a) & 0.54 \\
Carbon Monoxide (CO) & 0.51 \\
Nitrogen Oxides (NO $)$ & 1.21 \\
Sulfur Dioxide $\left(\mathrm{SO}_{2}\right.$ ) & 0.01 \\
Volatile Organic Compounds (VOC) & 1.14 \\
Hazardous Air Pollutants (HAPs) & 0.02 \\
Lead & 0.04 \\
\hline${ }^{(2)}$ Particulate matter equal to or less than 10 microns in diameter \\
\hline
\end{tabular}

An estimated 3.41 tons of criteria air pollutants were released on the NTS in 2007. The majority of the emissions were nitrogen oxides from diesel generators and VOCs from the bulk storage of gasoline. Total air emissions of lead, also a criteria pollutant, was 0.04 tons. The quantity of HAPS released in 2007 was 0.02 tons. No emission limits for any air pollutants were exceeded, and there were no discharges of nonradiological hazardous materials off the NTS or off its satellite facilities in 2007. 


\section{Offsite Radiological Monitoring of Groundwater}

NNSA/NSO's comprehensive radiological environmental monitoring program includes sampling and analysis of groundwater and natural springs off of the NTS to determine if groundwater contamination from past nuclear testing poses a current threat to public health and the environment. In 2007, NSTec conducted radiological monitoring of 14 offsite wells and 4 offsite springs. The wells included 4 private or community drinking water wells, and 10 NNSA/NSO wells drilled for hydrogeologic investigations including groundwater flow modeling. All of the NSTec-sampled wells and springs are in Nevada within 19 miles from the western and southern borders of the NTS (see map on page 17).

The DRI, through the CEMP, is tasked by NNSA/NSO to provide independent verification of the tritium concentrations in some of the offsite groundwater wells, municipal water supply systems, and springs used for water supplies in areas surrounding the NTS. Samples collected by DRI provide a comparison to the results obtained by NSTec. In 2007, the CEMP offsite water sampling locations included 21 wells, 3 surface water supply systems, and 4 springs located in selected towns and communities within 240 miles from the NTS (see map below).

NSTec offsite water samples are analyzed for tritium, man-made gamma-emitting radionuclides, and gross alpha and gross beta radioactivity. Tritium is the sole radionuclide for which CEMP water sample analyses are run.

\section{Tritium}

No offsite springs, surface water supplies, or wells had levels of tritium that were significantly above the minimum detectable concentration of 26 picocuries per liter $(p C i / L)$.

All water samples from the offsite springs, wells, and surface water supplies monitored by NSTec and the CEMP had levels of tritium below the approximate minimum detectable concentration (MDC) of $26 \mathrm{pCi} / \mathrm{L}$, except for the Henderson municipal water system sample of $32.2 \mathrm{pCi} / \mathrm{L}$. The water in samples from Henderson originate from Lake Mead. Slightly elevated tritium activities in Lake Mead are well documented by

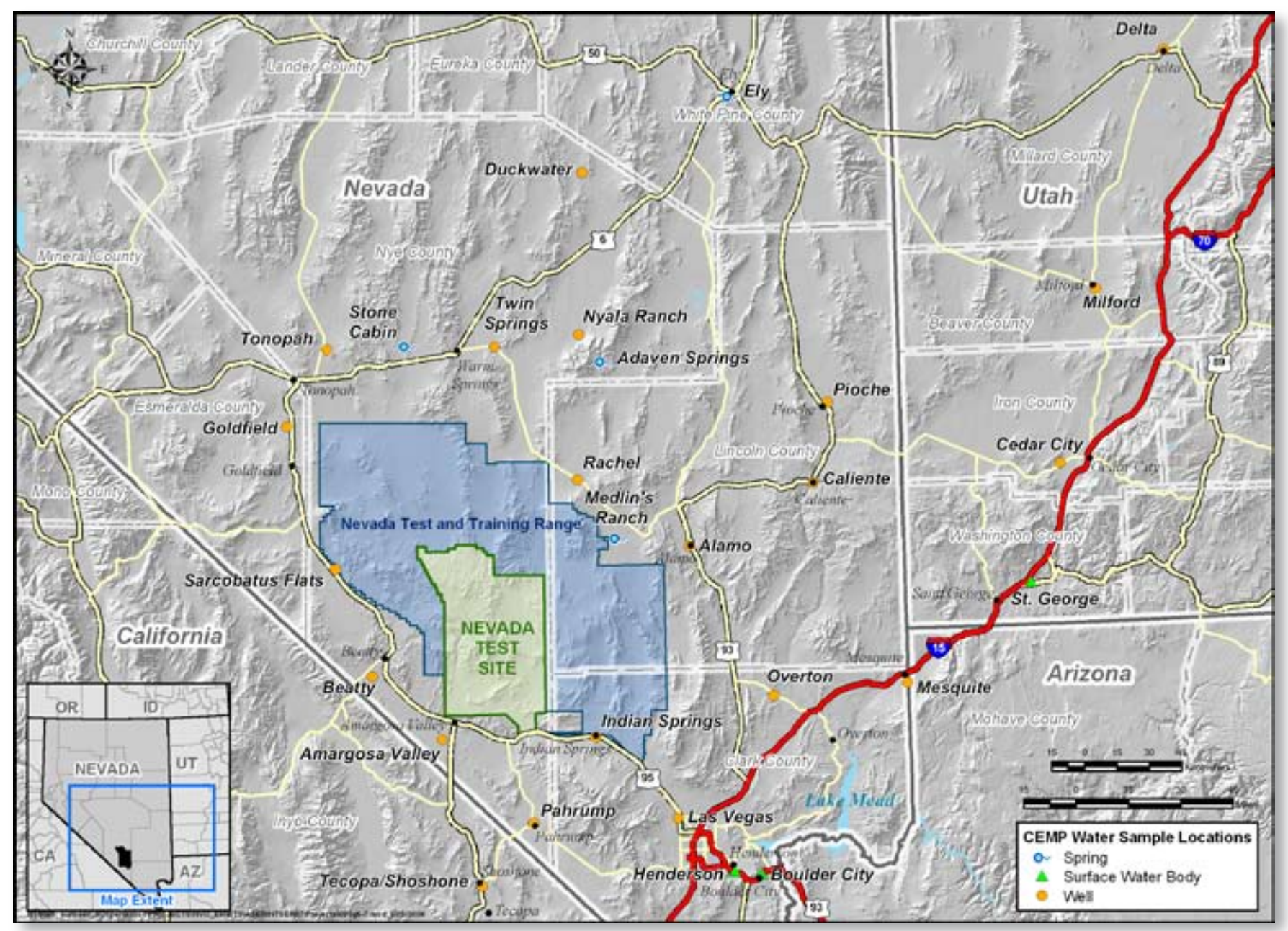




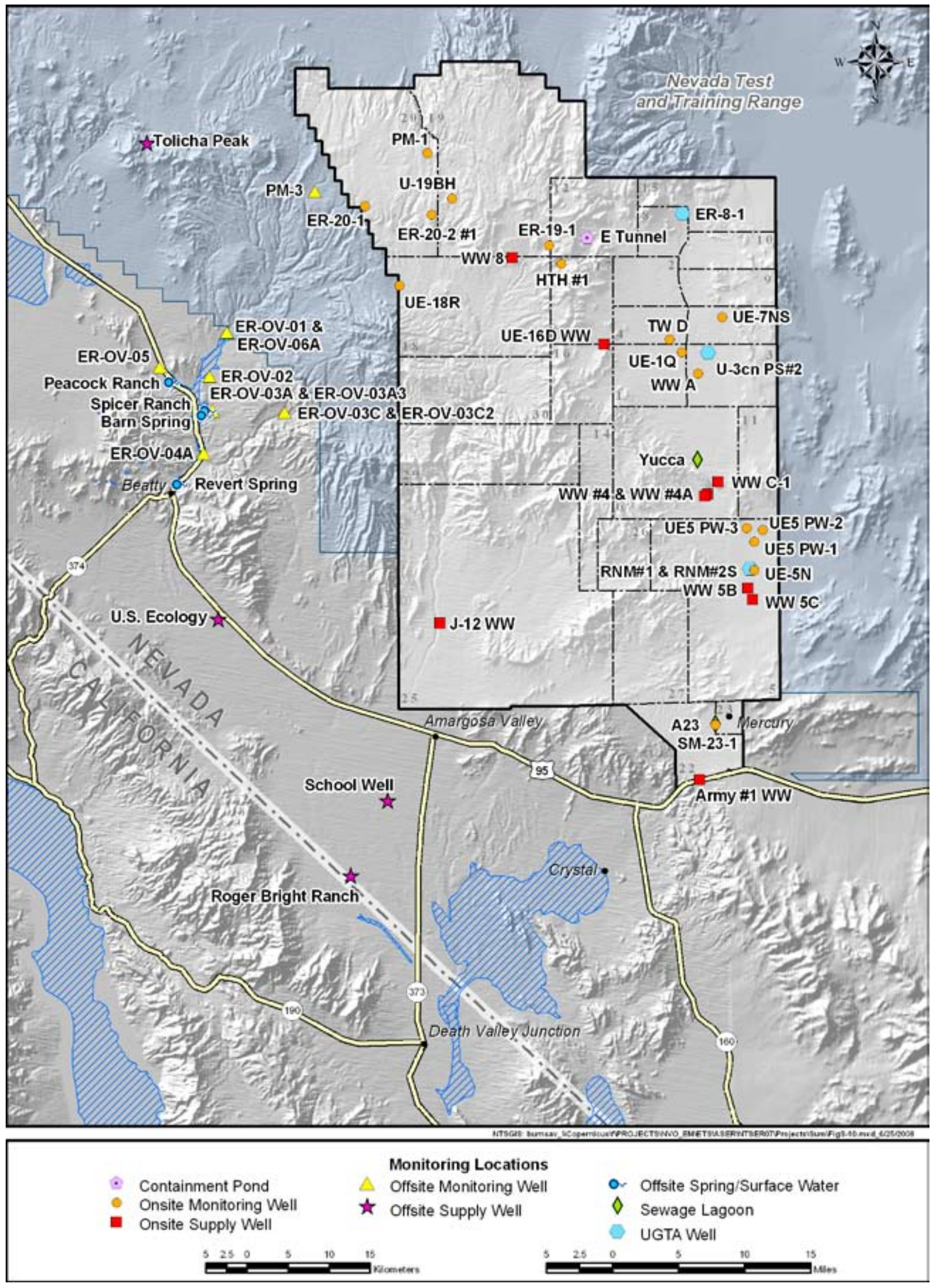


previous investigations and are due to residual tritium persisting in the environment that originated from global atmospheric nuclear testing.

No offsite springs or wells contained any man-made gamma-emitting radionuclides.

Most offsite wells

20,000 $p C i / L-T h i s$ is the EPA-established maximum concentration limit for tritium in drinking water.

and all offsite spring samples contained detectable gross alpha and gross beta activity that is most likely from natural sources. All levels were less than the

\section{Gamma-Emitting Radionuclides}

No offsite springs or wells contained any man-made gamma-emitting radionuclides.
U.S. Environmental Protection Agency (EPA) limits set for drinking water (15 pCi/L for gross alpha and $50 \mathrm{pCi} / \mathrm{L}$ for gross beta), except Barn Spring. This spring's measured gross alpha activity was $19 \pm 2.4 \mathrm{pCi} / \mathrm{L}$.

\begin{tabular}{l}
$\begin{array}{l}\text { Range in Groundwater Tritium Levels } \\
\text { Measured Off the NTS in } 2007\end{array}$ \\
\hline \multicolumn{2}{|c|}{ pCi/L } \\
\hline \multicolumn{3}{|c|}{ CEMP } & NSTec \\
\hline $\begin{array}{l}\text { Offsite Supply Wells } \\
\text { Offsite Springs/ } \\
\text { Surface Waters }\end{array}$ \\
$\begin{array}{l}\text { Offsite NNSA/NSO } \\
\text { Monitoring Wells }\end{array}$ \\
\hline $\begin{array}{l}\text { *Only one sample (from Henderson municipal water } \\
\text { system) was above the MDC. The MDC is the } \\
\text { smallest amount of tritium in a sample that can be } \\
\text { distinguished from background radiation in the sample } \\
\text { with 95\% confidence. }\end{array}$ \\
\hline
\end{tabular}

Offsite monitoring indicates that there has been no offsite migration of man-made radionuclides from NTS underground contamination areas.

\section{Onsite Radiological Monitoring of Groundwater}

Radioactivity in onsite groundwater and surface waters of the NTS is monitored annually in order to (1) ensure that NTS drinking water is safe, (2) determine if permitted facilities on the NTS are in compliance with permit discharge limits for radionuclides, (3) estimate radiological dose to onsite wildlife using natural and man-made water sources, and (4) determine if groundwater is being protected from disposed radioactive wastes at the Area 3 and Area 5 RWMSs. In 2007, the onsite water monitoring network consisted of 5 potable and 4 non-potable water supply wells, 16 monitoring wells, 1 tritiated water containment pond system, and 2 sewage lagoons (see map on page 17).

Water Supply Wells - The 2007 data continue to indicate that underground nuclear testing has not impacted the NTS drinking water supply network. None of the onsite water supply wells had detectable concentrations (i.e., above MDC) of tritium or detectable concentrations of man-made gammaemitting radionuclides. The gross alpha and gross beta radioactivity detected in potable water supply wells represent the presence of naturally occurring radionuclides and did not exceed EPA limits drinking water limits.

Jo drinking water wells on the NTS
contained detectable tritium or
man-made gamma-emitting radionuclides.

\begin{tabular}{|lc|}
\hline \multicolumn{1}{|c|}{$\begin{array}{c}\text { Range in Groundwater Tritium Levels } \\
\text { Measured On the NTS in } \mathbf{2 0 0 7}\end{array}$} \\
\hline & pCi/L \\
Onsite Supply Wells & -17 to 14 \\
Onsite Monitoring Wells & -16 to $390^{*}$ \\
\hline *Four onsite monitoring wells had tritium levels above \\
$\begin{array}{l}\text { MDCs and all four are within } 1 \text { kilometer (0.6 miles) of } \\
\text { underground nuclear tests. }\end{array}$ \\
\hline
\end{tabular}

Monitoring Wells - Some migration of radionuclides from the underground test areas to NTS monitoring wells has probably occurred, although the migration distances appear to be very short. Four onsite monitoring wells (PM-1, UE-7NS, U-19BH, and WW A) had detectable concentrations of tritium in 2007 ranging from 23 to $390 \mathrm{pCi} / \mathrm{L}$, all well below the drinking water limit of $20,000 \mathrm{pCi} / \mathrm{L}$. Each of these monitoring wells is located within 0.6 miles of an historical underground nuclear test; all have consistently had detectable levels of tritium in past years, and no trend of rising tritium concentrations in these wells has been observed since 2000 .

No man-made radionuclides were detected by gamma spectroscopy analyses at concentrations above detection limits in any of the monitoring wells in 2007. All of the 16 monitoring wells had measurable gross alpha and gross beta levels, which are likely from natural sources. Only one of the monitoring wells (ER-19-1) had gross alpha and gross beta activity above the EPA 
limits for drinking water. The activity levels in ER-19-1 is consistent with the levels reported from past years' sampling and may likely be attributed to elevated levels of dissolved solids.

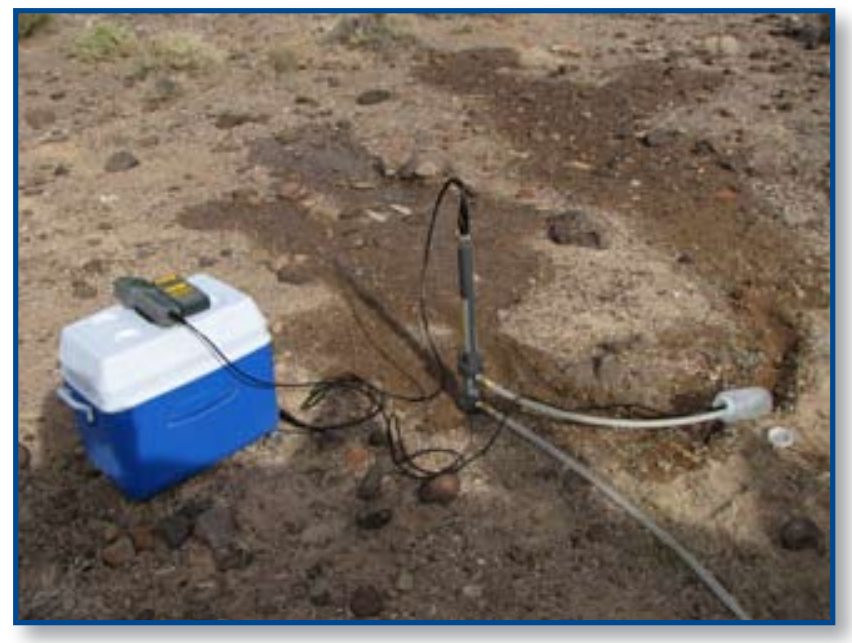

Sampling Oasis Valley, May 2008 (photo by Terry Sonnenburg)

Containment Ponds - Five constructed basins collect and hold water discharged from E Tunnel in Area 12 where nuclear testing was conducted in the past. The water is perched groundwater that has percolated through fractures in the tunnel system. Monitoring of the effluent waters from E Tunnel is conducted to determine if radionuclides or other contaminants exceed the allowable contaminant levels regulated under a state water pollution control permit. Tritium concentrations in tunnel effluent waters in 2007 were lower than the permit limit. The E Tunnel containment ponds are fenced and posted with radiological warning signs. Given that the ponds are available to wildlife, game animals are sampled by NSTec to assess the potential radiological dose to humans via ingestion of game animals exposed to these ponds and to evaluate the radiological impacts to wildlife.

Tritiated water is also pumped into lined sumps during studies conducted by the Underground Test Area (UGTA) Subproject. Its mission is to characterize the groundwater beneath the NTS and adjacent lands for the purpose of developing analytical models to predict groundwater movement and contaminant transport. To do this, suitable wells are drilled and existing wells re- completed in the vicinity of some underground tests and at other locations on the NTS. If the tritium level exceeds $200,000 \mathrm{pCi} / \mathrm{L}$ during these drilling operations, contaminated water is pumped from the wells and diverted to lined sumps (containment ponds) for evaporation, as required by the state. During 2007, water containing tritium was pumped from two wells in Area 5 (RNM \#1, RNM \#2S) and one in Area 3 (U-3cn PS \#2). Only the waters discharged from U-3cn PS \#2 needed to be diverted to a lined sump. Tritium levels were 7.7 million $\mathrm{pCi} / \mathrm{L}$ in groundwater samples from this well.

Permitted Sewage Lagoons - Two permitted sewage lagoons (Area 6 Yucca and Area 23 Mercury) are sampled annually and analyzed for tritium, gross alpha and beta activity, and gamma-emitting radionuclides. As during previous years, none of these were detected in the lagoon water samples.

\section{Onsite Nonradiological Monitoring of Drinking Water and Wastewater}

NNSA/NSO operates a network of six permitted wells that comprise three permitted public water systems on the NTS which supply the drinking water needs of NTS workers and visitors. NNSA/NSO also hauls potable water to work locations at the NTS that are not part of a public water system. Monitoring results for 2007 indicated that water samples from the three public water systems and from the potable water hauling trucks met the National Primary and Secondary Drinking Water Standards.

Industrial discharges on the NTS are limited to two operating sewage lagoon systems, one at Yucca Lake in Area 6 and one at Mercury in Area 23. Under the conditions of state of Nevada operating permits, liquid discharges to these sewage lagoons are tested quarterly for biochemical

\begin{tabular}{|c|c|c|}
\hline Parameter & $\begin{array}{l}\text { State Water Pollution } \\
\text { Control Permit Limit } \\
\qquad(\mathrm{pC} / \mathrm{L})\end{array}$ & $\begin{array}{c}\text { Average Measured } \\
\text { Concentration } \\
(\mathrm{pCi} / \mathrm{L})\end{array}$ \\
\hline Tritium & $1,000,000$ & 590,000 \\
\hline Gross Alpha & 35 & 12.1 \\
\hline Gross Beta & 100 & 49.3 \\
\hline
\end{tabular}

oxygen demand, $\mathrm{pH}$, and total suspended solids. Sewage lagoon pond waters are sampled annually for a suite of toxic chemicals. Quarterly and annual analyses of sewage influent and of pond waters, respectively, showed that all water measurements were within permit limits (often below detection levels) with one exception. One measure of 5-day Biological Oxygen Demand $\left(\mathrm{BOD}_{5}\right)$ Mean Daily Load was exceeded at the Area 23 Mercury lagoons in the fourth quarter. 


\section{Significant Environmental Accomplishments}

\section{Environmental Restoration}

The cleanup of sites contaminated by past DOE operations and the hydrogeological investigations supporting characterization of underground nuclear contamination areas are the most significant environmental work performed by NNSA/NSO each year. The DOE, U.S. Department of Defense, and the State of Nevada Division of Environmental Protection identify a work scope and milestone schedule for the cleanup and safe closure of the contaminated aboveground sites and for the field investigations and model development necessary to characterize the underground sites. In 2007, 114 contaminated aboveground sites were closed safely. These aboveground sites consist of facilities and land, and are referred to as Industrial Sites. In addition to the Industrial Sites closures, extensive progress was made toward the development of hydrologic models describing groundwater flow and possible radionuclide transport from the primary underground sites into the groundwater underlying public lands outside the boundaries of the NTS. This involved completing the compilation, analysis, and documentation of all transport parameters which will be used to build the flow model for CAU 98 (Yucca Flat/Climax Mine) and completing the 3D hydrostratigraphic framework model for CAU 99 (Rainier/Shoshone).

\section{Pollution Prevention and Waste Minimization}

Pollution prevention and waste minimization activities on the NTS result in reductions to the volume and/ or toxicity of waste generated on site. In 2007, the Material Exchange Program diverted 1.2 tons of chemicals, office supplies, and equipment from solid and hazardous waste landfills in 2007 and a total of 210 tons of usable materials from such landfills since the program's inception in 1998. Other significant waste reduction efforts continued in 2007, such as sending bulk used oil to an offsite vendor for recycling (76.6 tons), and offsite recycling of mixed paper and cardboard (606.2 tons). Overall, a reduction of 167 tons of hazardous wastes and 1,698.5 tons of solid wastes was realized in 2007.

NNSA/NSO received an Environmental Stewardship Award in 2007 for the renovation project of Building B-3 at the NLVF. Building B-3 had been vacant for two years, and rather than demolish it, NNSA/NSO decided to remediate, renovate, and upgrade it. This project resulted in extending the life cycle of the building, reconfiguring office space to increase capacity, conserving resources, reducing waste material going to landfills, contributing to recycling efforts, and eliminating a 20-mile round-trip drive for displaced employees. It also may result in Building B-3 receiving a certification under the Leadership in Energy and Environmental Design (LEED) Green Building Rating System administered by the U.S. Green Building Council.

In 2007, NSTec also removed 1,180 tons of unneeded raw materials that had been stored in the open at the NLVF. Needed materials were moved inside or covered. This cleanup project eliminated any potential to pollute storm water and resulted in the recycling of 413 tons of material. This action also exempted the facility from conducting difficult and costly monitoring of storm water runoff and other compliance actions required under the Clean Water Act.

\section{Ecological Monitoring}

NTS biologists performed numerous surveys and mitigation actions under permit with the U.S. Fish and Wildlife Service to ensure that no desert tortoise was accidentally harmed or killed during NTS activities in 2007. The desert tortoise is protected as a threatened species under the Endangered Species Act and it occurs in suitable habitat on the southern third of the NTS. Numerous species, considered by federal and state agencies to be sensitive or important to track, are known to occur on the NTS and include 20 plants, 1 mollusk, 2 reptiles, over 250 birds, and 26 mammals.

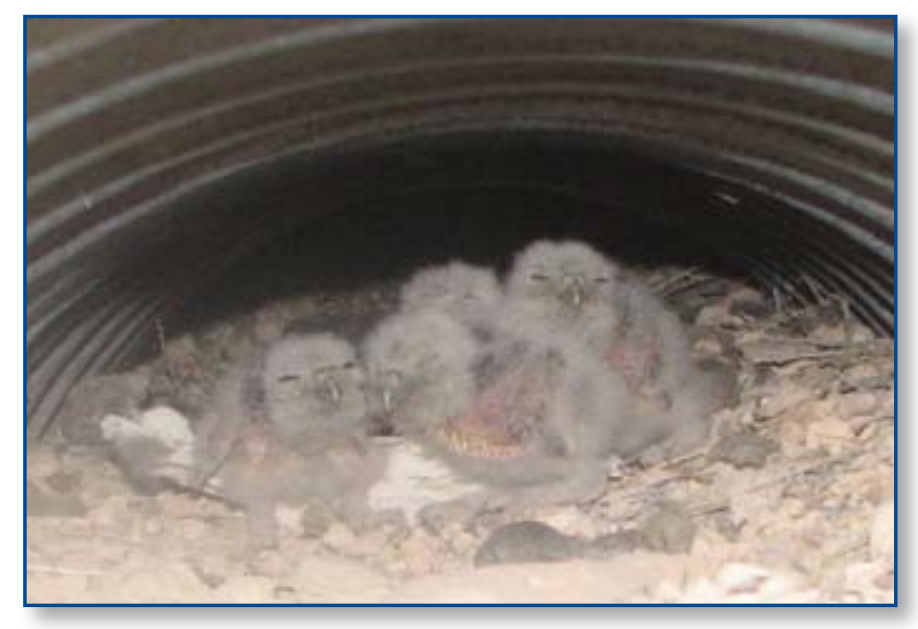

8- to 10-day-old western burrowing owl chicks in culvert burrow on Pahute Mesa (Photo by D. B. Hall, June 20, 2007) 
Biologists continued to monitor some of these species in 2007, which included western red-tailed skinks, western burrowing owls, bats, and mountain lions. As a result, the documented distribution patterns of these species on the NTS have been increased, and other species new to the NTS have been recorded. Data on species' movements, genetic relationships, and activity patterns have been gathered using the latest research techniques including DNA analysis, radio-isotopic analysis, and motion-activated cameras.

Biologists continued working in cooperation with Southern Nevada Health District (SNHD) personnel to determine if mosquitoes on the NTS carry West Nile Virus. As in previous years, no infected mosquitoes were found.

\section{Cultural Resources}

The ongoing historical evaluation of the nuclear testing tunnels in Rainier and Aqueduct mesas on the NTS is the first time anywhere that horizontal nuclear test beds have been studied for their historical significance. The tunnels are treated as historic landscapes and the importance of their contributions to the Cold War effort have qualified them to be exempted from the rule that buildings and structures must be at least 50 years old to be considered for the National Register of Historic Places. With this exemption, the $\mathrm{B}$ and $\mathrm{E}$ tunnels have been determined eligible to the National Register of Historic Places. This significant determination will allow the tunnels' historic landscapes to be preserved in place. 


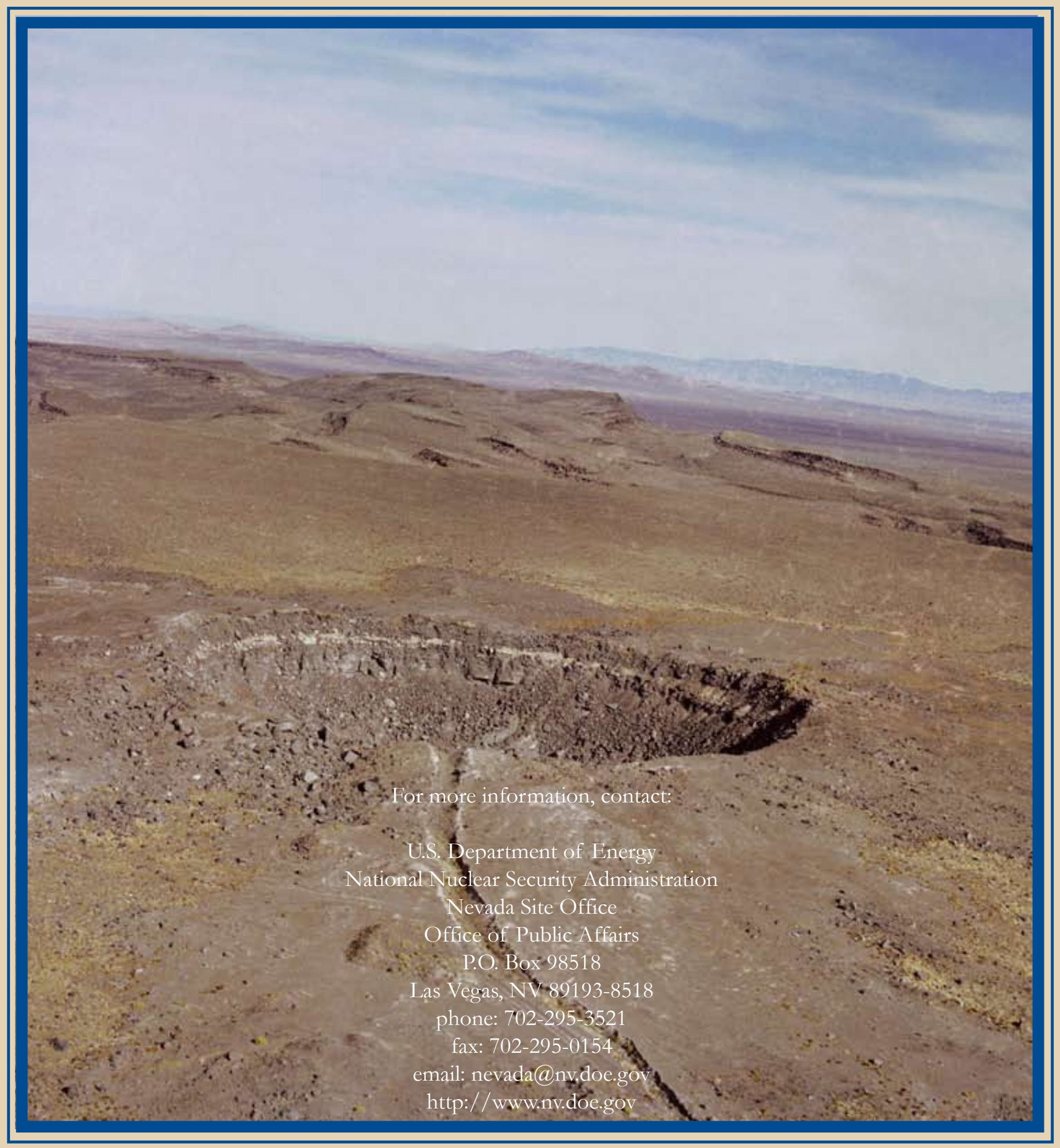

